\title{
Dutch Dealings with the Delta
}

Anna J. Wesselink

University of Twente

Department Water Engineering and Management

AUTHORS ' COPY

Faculty of Engineering

PO Box 217

7500 AE Enschede

The Netherlands

e-mail a.j.wesselink@utwente.nl

tel. +.31 .53 .4892615$

Wiebe E. Bijker

Maastricht University

Department Technology \& Society Studies

Faculty of Arts and Social Sciences

PO Box 616

6200 MD Maastricht

The Netherlands

e-mail W.Bijker@tss.unimaas.nl

tel. +31.43.388.33.21

Huib J. de Vriend

WL Delft Hydraulics

PO Box 177

2600 MH Delft

The Netherlands

e-mail Huib.deVriend@ wldelft.nl

tel. +31.15.285.89.37

Maarten S. Krol

University of Twente

Department Water Engineering and Management

Faculty of Engineering

PO Box 217

7500 AE Enschede

The Netherlands

e-mail m.s.krol@utwente.nl

tel. +.31 .53 .4892615$

Anna Wesselink was trained as a tropical land and water development engineer, then moved into water resources research and management. This took her to the UK, the Central African Republic, and Madagascar. In order to reflect on her professional practice, she started a Ph.D. on the decision-making process in flood management in the Dutch Meuse, with particular attention to the integration of expertise, the participation of relevant social groups, the ways integrated assessment is framed, and processes of (social) learning and negotiation. In her $\mathrm{Ph} . \mathrm{D}$. she integrates natural and social sciences and the humanities. 
Wiebe E. Bijker is professor of Technology \& Society at the University of Maastricht. He was trained as an engineer in physics (Technical University of Delft), studied philosophy (University of Groningen), and holds a PhD in the sociology and history of technology (University of Twente). Bijker is Director of Studies of the research master (MPhil) Cultures of Arts, Science, and Technology (CAST). Bijker's research focuses on the relation between technology, society, and science. Since the 1990's political and normative issues have been central. His most recent work relates to issues of vulnerability in a technological culture.

Huib J. de Vriend received his MSc in civil engineering and his $\mathrm{PhD}$ in technical sciences from Delft University of Technology. He has been project engineer and R\&D advisor at Delft Hydraulics and Professor of Integrated Modelling at the University of Twente. At present he combines the position of Director Science \& Technology of Delft Hydraulics with that of part-time Professor of River Engineering and Morphology at Delft University of Technology. He is a member of the Netherlands Expertise Network on Flood Defence and the Netherlands Commission for the Environmental Impact Assessment and he is actively involved in the research platform Netherlands Centre for River Studies (NCR).

Maarten S. Krol, having obtained a $\mathrm{PhD}$ in applied mathematics, worked for over 10 years on integrated modelling of climate change and the integrated assessment of climate change impact on water systems: at the National Institute for Public Health and the Environment (RIVM) in the Netherlands, the Potsdam Institute for Climate Impact Research (PIK) in Germany and the Federal University of Ceará (UFC) in Brazil. He is currently associate professor in integrated modelling for water management at the University of Twente. His research focus is on mathematical simulation for integrated assessment and on participatory scenario analysis in strategic policy development. 


\section{Abstract}

This paper shows how Dutch technological culture has historically dealt with, and developed around, vulnerability with respect to flooding, and indicates recent developments in attitude towards the flood threat. The flooding of New Orleans in the wake of Katrina temporarily made the Dutch public worry about the flood defense infrastructure in the Netherlands, exemplified by the Delta Works. Could this happen in the Netherlands? After the flooding disaster of 1953, a system of large dams was built to offer safety from flooding with - in theory at least - protection levels that are much higher than in New Orleans. In the public's perception the protection offered is absolute. In practice not all flood defense structures are as secure as they are supposed to be, but their upgrading takes time and money. Katrina has served as a reminder of what is at stake: can the Dutch afford to take another ten years to restore the protection level of their flood defenses? Calls for pride in clever engineering are the latest input into a continuing debate on the best way to continue life below sea level.

Keywords: flood management; resilience; policy making; technological lock-in; political lock-in; public perception

\section{Flood Management in The Netherlands}

The Netherlands at present has a land area of 42,000 square kilometers and a population of around 16 million. Around $25 \%$ of the country lies below mean sea level and without the current protection, $65 \%$ would be susceptible to flooding from sea and rivers. The country consists of the combined deltas of the rivers Rhine and Meuse and the smaller Scheldt and Ems. This area below sea level is protected from the sea and the rivers by natural dunes, manmade dikes and small-scale flood defense structures, and larger-scale dams such as the Afsluitdijk and the dams of the Delta Works. Although the eastern part of the country is a little higher, much of it still needs protecting from river floods. For many centuries the autonomous and democratic institutions of 'water boards' have organized the protection from flooding. From the early $19^{\text {th }}$ century onwards, the national water agency Rijkswaterstaat ${ }^{1}$ progressively gained power. Decision making and funding is at present in the hands of the national government, particularly the Ministry of Transport, Public Works and Water Management of which Rijkswaterstaat is a department. However, the responsibility for maintaining the dikes is still with the waterboards.

This essay describes the history of the interaction between the Delta and the Dutch, with the present hydraulic socio-technical ensemble as the outcome. This result can be understood as the Dutch way to deal with vulnerability associated with floods. There are signs that the views on flood defense are changing, but whether this will result in substantial modifications in the socio-technical ensemble remains to be seen.

\footnotetext{
${ }^{1}$ Central state agency for infrastructural works, at present part of the Ministry of Transport, Public Works and Water Management
} 


\section{Living in a Delta Means Dealing with Flood Risks}

Some 5000 years ago the first settlers in what is now the western and northern part of the Netherlands found themselves in a poorly drained delta area. Here, the rivers Rhine, Meuse and Scheldt meet the North Sea. Much of the land was regularly flooded, either from the sea in a 12-hourly tidal cycle, or by river water in the annual winter floods. These first inhabitants settled on naturally formed high areas: the coastal dunes or the natural levees along the rivers. Due to the unpredictability of frequency and intensity of flooding, this was a precarious existence. Meanwhile, the accumulation of peat in the lower areas surrounding them was continuing as it had done since the last Ice Age (10,000 years earlier). Around the year 1000 $\mathrm{AD}$ the level of the peat had risen to 2-3 m above mean sea level, allowing permanent habitation and agricultural use (Huisman 1998). The gradual population growth and the rise in demand for food crops encouraged the cultivation of this 'wild' land. Drainage ditches were dug and fields prepared (Te Brake 2002). As a consequence of the drop in groundwater level, the peat subsided, ${ }^{2}$ so ditches had to be deepened. Lack of flooding also meant no more sediment deposition, so the drop in level could not be made up by new layers of soil.. Canals were soon added to facilitatie the evacuation of water, starting a cycle of more subsidence more drainage efforts, etc. Through this early land and water management system, more and more land could be cultivated, which in turn helped generate the surplus revenue needed to maintain the system.

It was not just a success story though. The sea level was rising relative to the land because of the above mentioned subsidence processes, as well as larger scale climatic and geological processes. ${ }^{3}$ As a result, the probability of flooding increased. The $12^{\text {th }}$ and $13^{\text {th }}$ centuries in particular saw a series of devastating floods that swept away large tracts of cultivated land and several villages (Huisman 1998). As a consequence, the area of Netherlands was much smaller in $1500 \mathrm{AD}$ than in $0 \mathrm{AD}$ (Figure 1). Clearly, drainage alone was not enough any more. From around 1200 dikes (man-made levees) were constructed to protect the land, enclosing the famous polders. ${ }^{4}$ The development of powerful windmills in the $16^{\text {th }}$ century enabled drainage against gravity, which meant ever lower lying land could be cultivated.

\footnotetext{
${ }^{2}$ When drained, peaty mud land looses water, and decreases in volume. At the same time, drained peat soil oxidizes when in contact with the air which causes even more volume loss.

${ }^{3}$ This is due to the re-establishment of mass equilibrium between Scandinavia and the Low Countries after the end of the last Ice Age. Scandinavia is still bouncing back, having lost the weight of the ice. This causes the Netherlands to subside.

${ }^{4} \mathrm{~A}$ polder is an area encircled by a closed dike system.
} 

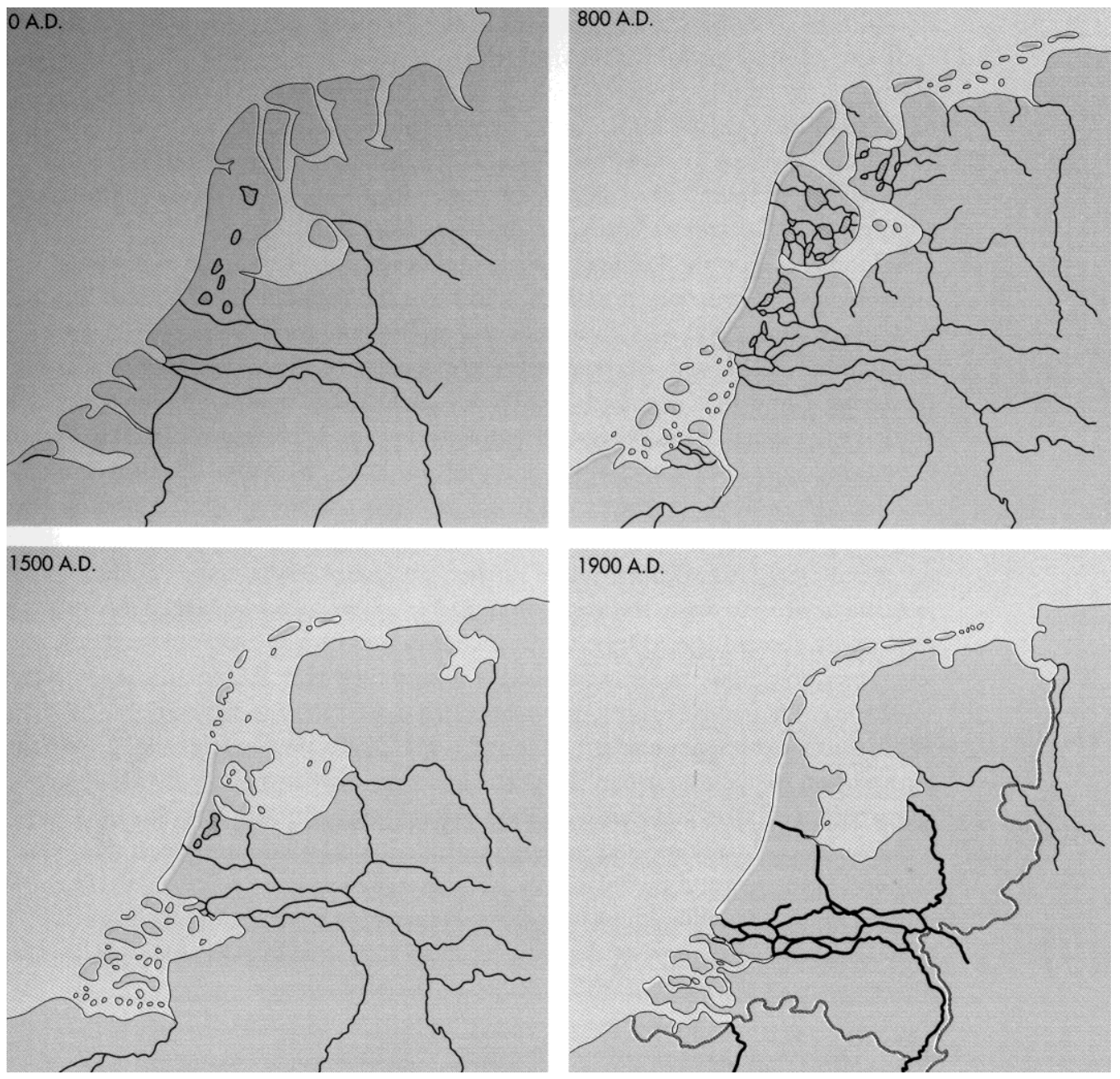

Figure 1 Physical development of The Netherlands since 0 AD. Courtesy Huisman 1998

These engineering developments are only one part of the evolving land and water management system: social and financial organization are other components. While drainage alone could be organized and financed on a village level, the technological knowledge, financial resources and organization needed to construct and maintain flood defense measures was of a larger scale and complexity. The organization of water management evolved from the village level upwards. As early as the $12^{\text {th }}$ century local committees had merged into regional water boards (Te Brake 2002). Their 'collective' rule, a balance between power and the need to cooperate, and autonomous status has been described many times as a prime example of democratic decision making (e.g. Bijker 1993; Kaijser 2002).

As time progressed, Dutch confidence in and their knowledge of hydraulic technology increased. In the Golden Age ( $17^{\text {th }}$ century) the surplus of riches generated through trade started to be invested in privately funded land reclamations. From an attitude of 'living with water' (through drainage) to 'protecting from water' (through dikes), the fight was now on how to regain what the encroaching water had taken. The first areas to be reclaimed were inland lakes. These, by the way, were the result of unsustainable peat extraction that fired the same economical wonder. Facilitated by the development of steam powered engines, parts of the sea were reclaimed from the late $19^{\text {th }}$ century. The last polders in the IJsselmeer were completed in 1968 (Figure 2). These projects were undertaken by the by then powerful national state organization, Rijkswaterstaat. The importance of the national state had received 
a boost when France, with a much more centralized state system, occupied the Netherlands (1795-1813) (Kaijser 2002). The institution of Rijkswaterstaat was modeled on the French Corps of Engineers and is now one of the lasting legacies of the occupation. With time it became 'the ruler of the Delta' (Lintsen 2002).

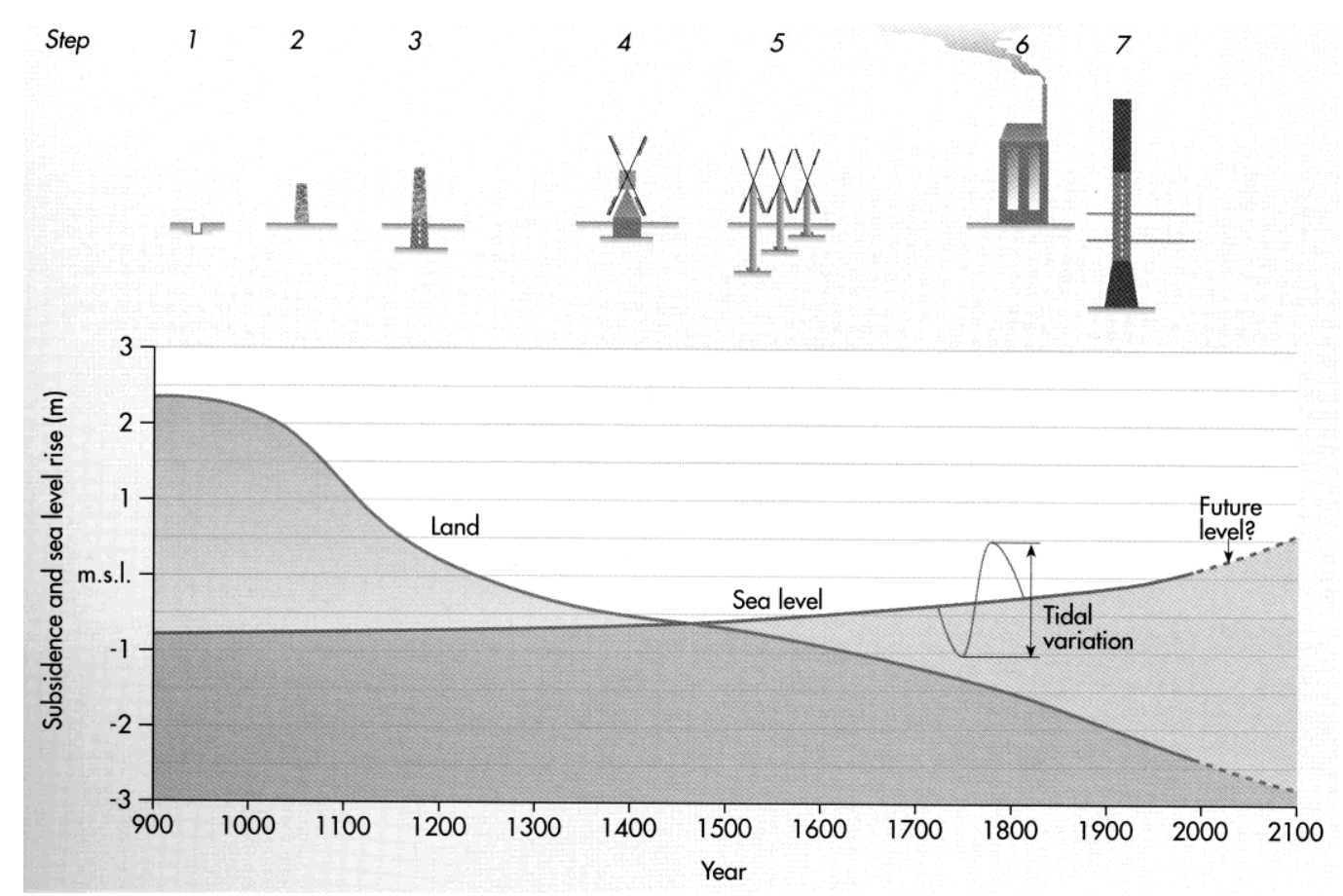

Figure 2 History of water management in The Netherlands. Courtesy Huisman 1998

Dutch political culture exhibits several characteristics that can be traced back to this history of water politics (Bijker 2002). First, there is a certain trust in technical solutions and the management system that set up and maintains these. To the outside world, policy makers, scientists and engineers form a closely-knit community that is not easily challenged and thus exhibits confidence. However, internally disagreements may be fundamental and discussions charged (Schwartz 1993). Related to the use of and trust in technology, the Dutch have a long tradition of planning and actively shaping their environment and believe that they can adjust it to suit their needs. Dutch political culture is generally depicted as consensual and oriented towards cooperation and compromise. This style of looking for consensus combined with a trust in the flood management system eventually results in a popular belief that everything is under control (see Section 6). At the same time, a sense of vulnerability remains because of the centuries-long threat from high water. In the event that the technical solutions fail, the Dutch have a capacity to react relatively swiftly to crises. Dutch politics will often take a pragmatic approach to find ad hoc and flexible solutions, even if this means flexibility in interpreting regulations and bypassing democratic procedures (Bijker 2002).

Since 'Dutch society' decided to drain the coastal wetlands, we have gradually maneuvered ourselves into a technological lock-in where only ever increasing efforts can keep the system operational (Wesselink 2006a). The drained land subsided (see note 2), so dikes were built. Lack of flooding prevented sediment deposition to compensate the subsidence. Dikes had to be raised again, and so on: The difference between the crest of the dikes and the land in some places now exceeds $10 \mathrm{~m}$, resulting in important consequences in case of failure (Figure 3 ). 


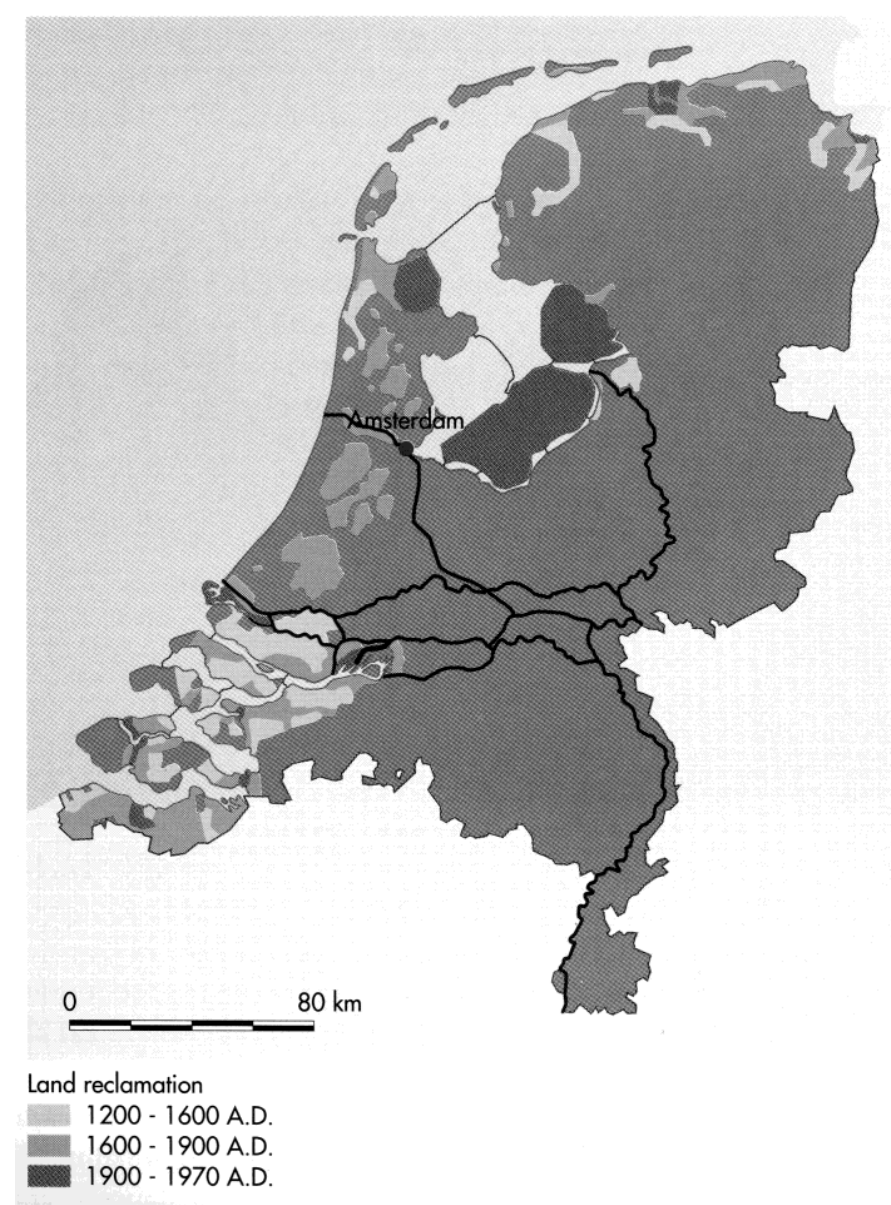

Figure 3 Land reclamation in The Netherlands since 1200 AD. Courtesy Huisman 1998

The frequency of flooding decreased as technological solutions became more sophisticated, but at the same time damage potential increased as more and more was invested in the protected land. When it all started with the small drainage ditches there was no question of a conscious decision that 'we settle and develop land in places where floods or droughts constantly threaten, and then expect technology to rescue us from our own irrational decisions' (Reuss 2002). Rather, at any moment in history the Dutch had to live with the reminders of previous rational decisions with their bounded temporal planning horizons and limited knowledge on consequences. The present Dutch hydraulic socio-technical ensemble is the result, including its weaknesses. ${ }^{5}$ And in 1953 these weaknesses became apparent again.

\section{The Flood Event of 1953 and its Wake: the Delta Works}

In the 1930's some in the engineering community had warned that the dikes in Zeeland, the estuary area in the southwestern part of the Netherlands (Figure ..) were not strong enough (Lintsen 2002). This might have been a reaction to the 1926 flooding of a large part of the river system between the Rhine and Meuse, but this link has not been investigated. The engineers prepared plans to close off the estuary (Van de Ven 1993), but no funds were allocated to this project. Money did get allocated to close off the inland sea Zuiderzee. Then the second World War intervened, and when the devastating storm surge happened in 1953

\footnotetext{
${ }^{5}$ For 'sociotechnical ensemble', see Bijker, 1995.
} 
the country was still focusing on more immediate needs such as rebuilding schools, houses and factories.

In the night of 31 January 1953 a spring tide combined with a long lasting north-westerly storm to set water levels up against the coasts in the funnel leading to the English Channel. In early morning of 1 February 1953 the dikes broke at over 900 locations in the Southwest. Very soon $2000 \mathrm{~km}^{2}$ of land was inundated. As there had been next to no warning and no evacuation policy or plan, the population was not prepared, and certainly not evacuated. The authorities did not imagine this could ever happen, which meant that rescue teams were slow to get moving. Word of the scale of the disaster was only slowly spreading. Because the area flooded was relatively sparsely populated (750,000 people were affected), the death toll was still relatively small with 1835 drowned. The effects were traumatic and long-lasting: for individuals and the region, but also for the country as a whole.

Once the extent of the disaster did become clear, national politics moved very rapidly. The Delta Commission was established and they picked up the plans made in the 1930's. The government did not await formal parliamentary approval of the plans before asking Rijkswaterstaat to start implementation of the Delta Plan.. All tidal outlets in the estuary were to be closed off, except the northern and southern waterways which provided access to the harbors of Rotterdam and Antwerp, respectively. Here the dikes were to be strengthened. The Delta Commission also proposed high safety standards for all flood defense structures, also those along the rivers. It was felt that flood protection measures had to be strong enough to withstand all but the most extreme events, either storm surges from the sea or river floods, depending on the location. In addition, the standards and their application were to be based on scientific criteria. Until that moment the dimensions of dikes had been based on the highest water level experienced, now statistics were employed (see Section 5). The expected damage, both in terms of human lives and economical damage, was the most important factor in determining the safety standards. Neither data nor appropriate models were available to make a quantitative assessment of the latter, and the protection standards were based on a qualitative judgment of the importance of protecting the different areas.

\section{Engineering Wisdom Challenged: the Ecologists' Turn}

When the implementation of the Delta Plan started, the scale and scope of the required engineering works were still largely untried. In order to gain experience the smallest dam was constructed first (Bijker 2002). Engineers and scientists worked closely together to learn from calculations, scale models and experiments and in this way to develop technologies appropriate for each site. When it was the turn of the last closure, the Oosterschelde dam, the engineers were ready for this largest project. However, by then public support for the closure of all tidal inlets had diminished considerably. It had become clear that an ecological disaster loomed: stagnant water and inflow of polluted river water had started to cause severe pollution problems in the recently closed off estuaries ${ }^{6}$. Also, the unique ecology of the last remaining watercourse, the Oosterschelde, was increasingly appreciated. An ad hoc alliance of fishermen, nature conservationists and the first ecologists to work in Rijkswaterstaat successfully challenged the proposed closure, much to the distress of several other parties who argued that the area already had been left unprotected for too long. Amongst these the majority of Rijkswaterstaat who, 'the heroes of the Delta Works, were quickly demoted to

\footnotetext{
${ }^{6}$ This is in the 1970's when water quality in the rivers was at an all-time low.
} 
shortsighted engineers' by the ecological lobby (Lintsen 2002). This decline in status still has an important influence on policy making as Sections 6 and 7 will show.

In 1974 the government decided to go ahead with the compromise option of a partial closure, although technically and financially it was not yet clear how this could be done. The complexity of the task was solved by drawing in more scientists and also, for the first time, the construction companies (Bijker 2002). After several technical-cum-political crises the storm surge barrier was opened in 1986. The dam consists of sliding doors between pillars that are normally open to allow the tides to flow in and out, but will close when high water levels are forecast (Figure 4). In this way almost half of the water area that would have been closed off now maintains an open connection with the sea. Ecologically, not all problems have been prevented but the ecological situation is considered much better than it would have been had the Oosterschelde become a stagnant fresh water lake (Smaal et al. 1991).

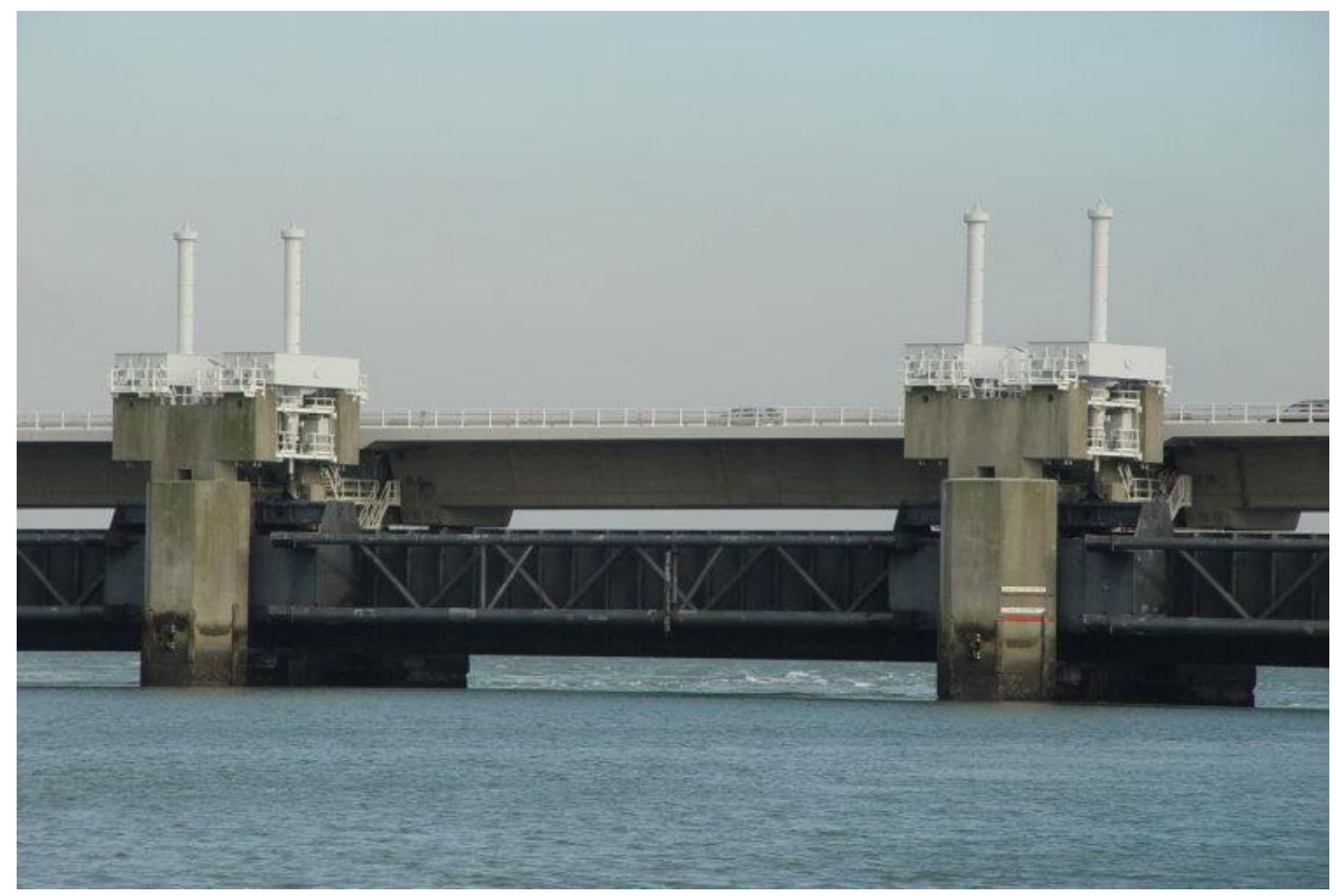

Figure 4 The Oosterschelde Dam Gates. From Bijker 2002

It can be argued that the Oosterschelde dam radically changed the world of water engineering in the Netherlands. Although achieving the safety levels was still obligatory, to maintain a good ecological status was added as an objective for the flood protection strategies. From this moment, ecologists gained a firm foothold in decision making on flood management in the Netherlands, also in the Rijkswaterstaat organization (Disco 2002). It is not surprising therefore, that recent developments in Dutch thinking about protection from river floods in the rivers Rhine and Meuse went in the same eco-friendly direction. To fulfill the promises made after the 1953 inundations, a round of dike reinforcements was started in the 1970's. Both local residents and nature conservationists interpreted this as a threat to the valued river landscape. Legal consultation requirements provided them with ample possibilities to delay decisions and implementation of plans, and Rijkswaterstaat's projects often ended in 
stalemate. The paradigmatic breakthrough came with the presentation of a vision to combine nature development and flood protection: Plan Stork (De Bruin et al. 1987). Floodplains in use for grazing or brick making had to be redeveloped as an 'original floodplain habitat'. The large scale reshaping of the floodplain necessary to implement these ideas would at the same time provide more space to convey river floods. As a result reinforcement of dikes would become unnecessary, and both engineers and nature proponents would be happy. Still, the dominant engineering paradigm could not be changed this easily. An investigation into technical solutions for landscape-friendly dike constructions was subsequently commissioned (Ministry of Transport, Public Works and Water Management 1993), but this was insufficient to convince the ecologists or residents. Dike reinforcements came to a halt for the time being while the new ideas of Plan Stork were only hesitantly put into practice in a few locations.

This all changed with a couple of near-flood events in the Rhine and Meuse in 1993 and 1995. The subsequent calls for more safety proved the push to bring at least the most critical stretches up to standard. These near-misses also reinforced the idea that the capacity of the system was limited, and that more resilience was needed. Although detailed calculations of hydraulics and economics showed that no easy solutions were possible, the water community picked up the basic idea of Plan Stork partly because of the increased resilience if naturally occurring processes in delta areas would be given space. The concept was incorporated in the national policy 'Room for the River' (Ministry of Transport and Water Management \& Ministry for Housing, Spatial Planning and Nature 1997). Contrary to Plan Stork the policy 'Room for the River' emphasizes the creation of space for water rather than nature development as a first objective.

In the early 2000's Plan Stork's aim to improve the quality of the landscape by creating dynamic nature areas was weakened further from its original purpose to create a natural river landscape. It was reformulated as 'enhancing spatial quality' to indicate that multiple interests should be taken into account: nature, housing, recreation and business. As 'spatial quality' is a concept that can be interpreted in many ways, it offers possibilities to involve all interested parties in processes of consensus and compromise. 'Spatial quality' can even provide arguments for measures such as the sale of land in the floodplain for housing development, the proceeds of which could then be used to finance flood defense measures (Roth et al. 2006). Around the same time the slogan 'The Netherlands lives with water' was coined, reinforcing the idea that the population might enjoy to live near or in water instead of foremost considering it an enemy. A national PR campaign with this title was launched, as well as a large budget for many applied research projects, e.g. €45 million for 'Living with Water'. It would look as if Plan Stork's view of a natural floodplain able to accommodate high discharges has in a roundabout way provided arguments to make flood protection secondary to other demands. The policy moves towards 'spatial quality' and 'living with water' can be analyzed as a response to increasing environmental awareness (Meijerink 2005) as well as the need to intensively use the limited land available. This resulted in pressure from other ministries to be involved in flood defense projects. As a side effect maintaining flood defense standards became dependent of decisions made in other policy fields, where flood protection arguments are one of many to be considered.

\section{Reconsidering Flood Risks: What the Engineers are Saying}

While the ecologists proposed their Plan Stork, the engineering-cum-scientific community was also rethinking flood management strategies. They felt the need to review the procedures 
employed to calculate the potential impact of flooding and the strength of the flood defense system, implicitly questioning previous decisions based on these calculations.

The flood safety standards proposed by the Delta Commission (Section 3) were formulated using a statistical parameter: the frequency of exceedance. This indicates the statistical probability the design conditions for the flood defense system will be exceeded, and is expressed as $1 / \mathrm{n}$ per year. For the area where economic and protection stakes were highest a frequency of $1 / 10000(0.01 \%$ per year) was deemed acceptable; other areas would be protected at $1 / 4000(0.025 \%$ per year) or $1 / 1250(0.08 \%$ per year) (Figure 5$)$. Since polders are protected by dike rings, which also include all sorts of structures and anomalies, the current practice of checking dike sections is not sufficient. This means it is unknown whether the flood defense system meets the agreed safety levels even if the dikes are high and strong enough (and they often are not, see below). ${ }^{7}$

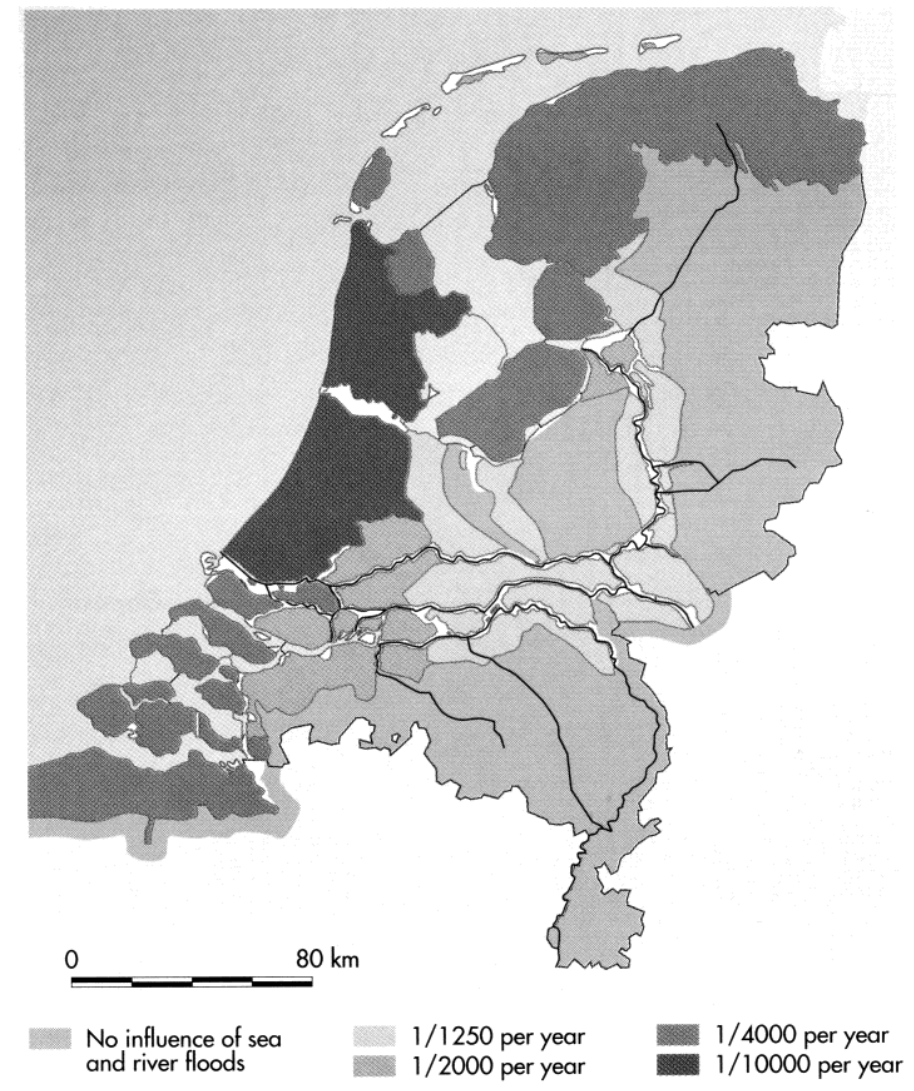

Figure 5 Legal flood protection levels in The Netherlands. Courtesy Huisman 1998

The other area that they felt needed reviewing was the value of the protected area. Since the 1960's when the safety levels were set, investments in infrastructure and property had increased tremendously and maybe the level of protection offered needed to be increased too. A formal and quantitative method of risk calculation should be developed in order to be able to weigh risks against the cost of protection. Based on this policy makers would be able to decide in an objective way whether and where money needed to be spent on improving the dikes.

\footnotetext{
${ }^{7}$ Of course, a higher dike is also wider and heavier, and design criteria ensure that slopes are small enough to ensure stability. Still, the basic fact remains that the legal obligation exists only to test the height against expected flood levels.
} 
Answering these pleas for more information, in 2000 a full scale investigation was started to include all failure mechanisms and damage calculations. It was baptized 'Flood Risks and Safety of the Netherlands'.. Results for 16 out of 53 polders were published in 2005 (Ministry of Transport, Public Works and Water Management 2005), and work is continuing on the other polders. With one or two exceptions the calculated protection was estimated to be lower than legal standards implied, often with a factor 10 or even 100. The official inventory found that nation-wide only $44 \%$ of the dikes and dunes definitely fulfill the legal standards, $24 \%$ definitely don't, and for $32 \%$ the situation is unclear through lack of data (Ministry of Transport, Public Works and Water Management 2006b). The subsequent requests from water managers to improve the situation were not very successful (see Section 6).

Parallel to these methodological developments, discussions on the uncertainty in the calculations of extreme discharges were gaining importance. Application of the legal safety standards required a single figure for water level, but how certain was this number if only 100 years of data are available to derive a probability of 1 / 4000 ? In most scientific fields extrapolation with a factor 40 would be frowned upon, here the protection of a large population was based upon it. Uncertainties were recognized to be at least an order of magnitude around the calculated probabilities. The expected impacts of climate change only increase the uncertainty, even if scientists try their best to understand and quantify the possible effects on flood frequency and magnitude.

Science and engineering were including more and more factors in their calculations in order to reflect better the complexity of failure mechanisms, societal and economic impacts of potential flooding, and uncertainties related to climate variability and change. Better representation of the facts should lead to better informed decisions. Here politics come in.

\section{Flood Safety Compromised?}

From sections 4 and 5 it appears that flood management policy in the Netherlands has been changing in two related directions. First, it has become intertwined with other policies e.g. on land use planning and nature conservation. Second, it has adopted a discourse where adaptation to floods is advocated. Both could imply a more flexible approach to flood protection standards. At the same time, the existing legal standards based on control of flooding remain in place. This means that two competing discourses on flood management strategies exist alongside each other, one of 'control' and one of 'accommodation', while in the past 'control' was the only option considered (Wiering \& Immink 2003). This could possibly indicate a shift in the perception of how to deal with vulnerability: from 'resistance' to 'resilience' (Bijker 2005). It could also be interpreted more cynically as a move to reduce spending on flood protection. The actual implementation of the policy can provide some insight into the way these discourses should be interpreted.

Section 5 demonstrated that a significant part of the flood defense structures are not fulfilling the legal standards. Politicians have hardly responded to these findings. The Deputy Minister for Water Management does 'not want citizens to panic unnecessarily [and] wants to wait for the full results of the study Flood Risks and Safety in the Netherlands [..]. The government 
had to implement budget cuts ${ }^{8}$. These are as many reasons not to increase the budget spent on regular maintenance of flood defense structures. It looks as if, like the chairman of the Union of Water boards says, 'safety against flooding is mainly a matter of a political will to invest' (Nieuwsbrief crisisbeheersing 2005). Bringing the existing dikes up the legal standards is now estimated to cost $€ 1,6$ billion, but only a fraction of this sum has been allocated (WaterForum Online 14 September 2006). Funds for the relatively innovative projects designed to implement 'Room for Rivers', costing $€ 2,2$ billion, have been more forthcoming (Ruimte voor de Rivier website 2006). Here, efforts are made indeed to combine flood defense with other objectives, e.g. nature or recreation, under the heading of 'spatial quality'. The policy also gives an opportunity to introduce more resilience, in this case by overdimensioning measures in order to create space for natural processes and flexibility to cope with climate change and other uncertainties (e.g. in hydraulic calculations). Funding for the reinforcement of coastal weak points has also been allocated. It looks as if the implementation of legal protection standards depends on circumstances.

In practice the outcome of the negotiations between the interested parties in Room for Rivers and related projects is often to fine-tune the proposed works in such a way that the fixed water level targets are met exactly (e.g. Wesselink 2006b, Steenhuisen 2006). This means that, although the concept of resilience is incorporated in the projects' objectives, in the implementation phase the resistance paradigm dominates. It is hard to see how this can change as long as the law is focused on achieving set protection levels.

The lack of political will to invest gives rise to the suspicion that the lofty goals of spatial quality and living with water could be used as an excuse to make flood defense projects dependent on (co-)financing from other ministries' budgets. Delays can then be blamed on partners' reluctance. In Section 4 it was shown that flood management policy moved from providing safety through dikes, dunes and dams (e.g. Ministry of Transport, Public Works and Water Management 1993) through explicit attention for nature in 'Room for rivers' to vague multiple objectives in 'spatial quality'. The most recent policy document 'Living in a dynamic Delta' (Ministry of Transport, Public Works and Water Management 2006a) moves further along this road. After establishing that 'due to climate change there will be increasing pressure on the Dutch delta' and 'we are looking at vital interests' it states that 'requirements for water should not always be given priority', 'other sources of finance [than the national budget]' should be found, and 'citizens and companies should be allowed to determine their own environment in relation to water' and start to 'take their own responsibility'.. While these might be obvious statements in countries where more responsibility has always been given to private parties, such as the USA, in the Dutch policy arrangement it is a (radical?) move away from the view that Father State can be trusted to look after the interests of all citizens. 'Living in a dynamic Delta' underpins the analysis that the national government is trying to reduce its expenditure on and even its responsibility for flood management. Other demands for the same space might be given priority, especially when they provide income. A concrete example of the latter is the decision to allow development of a housing estate in the lowest lying polder in Holland: the demand for space for housing is apparently more important than the additional risks that are generated. The Ministry's Deputy Director for Water Management justifies this decision by saying that 'we need to 'be innovative in our dealing with water, and allow exciting possibilities' (Wouters 2006). The chairman of the Union of Water boards sees it differently: 'Room for Rivers is becoming Room for Builders' (quoted in Roth et al. 2006).

\footnotetext{
${ }^{8}$ tv interview with Staatssecretaris (Deputy Minister) in Netwerk 22 February 2006, reported in Waterforum Onlinewaterforum online
} 
It thus appears that flexibility is certainly a characteristic of the recent flood defense projects, even when it is questionable whether it is a flexibility that increases resilience with respect to flood risks. When it comes to dealing with safety standards, the control paradigm still dominates, even when standards are not implemented in many places for a variety of reasons. The way 'resilience' is implemented means giving in to other demands for space for budgetary and political reasons, either on paper (Room for Rivers) or in reality (building in floodplains), but neither do in fact increase resilience. The failure to secure funding is thus masked as 'increasing spatial quality'. This failure ultimately lies with national politics.

\section{A Political Lock-in}

Politicians usually blame the low political priority on a lack of popular support for (spending money on) flood defense measures. Recent inquiries have indeed revealed that most members of the public are not interested in discussing water issues, not because they do not care but because they are confident that things are being looked after properly (Heems \& Kothuis 2006). In a recent survey the flood defense engineering indeed ranked first when people were asked to list great Dutch achievements (Visie21 2006). We doubt that people are not interested in what they are proud of, but they leave it to the national government to decide whether more money is needed for flood defense. These politicians are often primarily concerned with emerging issues and initiatives with short to medium planning horizons, such as the fight against terrorism, national health or the construction of new barrier gates (Berends 2004; Wesselink 2006a). Only briefly, e.g. after the near-flood events of 1993 and 1995 in the Rhine and Meuse or after Katrina in New Orleans, is the public confronted with the real possibilities that 'things can go wrong'. Reactions are strong, but soon forgotten when other events claim the limelight. Of course the media play an important part in this behavior. If they would decide that flood risks were unacceptable and start a concerted campaign to inform the public, they could change the policy scene. The role of the media is not further explored here.

The public's trusting attitude is constructed around aspects of Dutch culture introduced above. Their confidence in technical solutions was reinforced by the Delta works; the public believes that these constructions ensure that a disaster like the 1953 flooding will never happen again. Also, politicians emit the message that 'we have never been protected as well before', and 'nowhere is flood protection to such high standards as in the Netherlands' (Pool \& Ligthart 2004). After all, they want to be seen to fulfill the public's expectations in terms of providing safety even if scientific investigations show otherwise. The PR campaign 'The Netherlands lives with water' aims to raise risk awareness, but at the same time reinforces the view that all is under control by focusing on flood management projects about to be implemented. Raising public conscience on the risks that will inevitably remain is apparently still a step too far. When safety levels cannot be politically discussed due to a political fear of contradicting the public conception of absolute security, a fundamental revision of flood defense policy is unattainable. This represents a political lock-in, alongside the technological lock-in demonstrated in Section 2. ${ }^{9}$

\footnotetext{
${ }^{9}$ for political lock-in see e.g. Grabher 1993
} 


\section{Conclusion}

The Netherlands is truly finding itself in a lock-in because there is no question the whole population could move elsewhere. Its technological culture of flood defense is inseparable from the existence below sea level, for flood defense concerns the entire culture: history, society, economy, buildings and infrastructure. In view of the public's reaction to any flood event here or elsewhere it is unlikely they would accept otherwise. The protection from flooding provided by the dikes but especially by the technologically advanced Delta Works has created a false sense of security in the Dutch delta. Here, 'low frequency' means 'low priority' but also 'high consequence': if things would go wrong, they would go seriously wrong, considering the high population and economic densities. The population feels secure and is not prepared to accept any thought of vulnerability. In their view it is the government's job to ensure everything is taken care of. The government, meanwhile, reckons it cannot spend more money on flood defense saying there is no public support for it. By insisting that legal standards are actually met, they encourage the popular belief that everything is all right.

Water professionals are trying to break this vicious circle by quantifying the risks. They indicate that probabilities of failure are much higher than expected and consequences too. Alternative legal embeddings of flood defense levels, however, will face exactly the same political difficulties as the present system. Safety levels by definition reflect the compromise choice between efforts for protection and implicitly accepted residual risks. If safety levels cannot be politically discussed due to fear of contradicting the public perception of absolute security, a revision of flood defense policy is unattainable. Consequences of this position are e.g. low priority for spending money on flood defense, politicians arguing that flood protection is only one of many objectives, proposals to combine flood defense with (more economically advantageous) land uses, and arguments that money preferably should be found elsewhere than in the national treasury. This political lock-in may be as decisive for long-term vulnerability as the technological one as it prevents fundamental discussions on a way out.

\section{I have squandered my resistance for a pocket full of mumbles, such are promises (lyrics of The Boxer, Paul Simon)}

\section{References}

Berends, Paul. 2004. pers.comm.

Bijker, Wiebe E. 1993. Dutch, dikes and democracy. An argument against democratic, authoritarian, and neutral technologies. Technology Assessment Texts no. 11. Unit of Technology Assessment, Technical University of Denmark, Lyngby, Denmark.

- 1995. Of Bicycles, Bakelites, and Bulbs. Toward a Theory of Sociotechnical Change. Massachusetts Institute of Technology Press, Cambridge Massachusetts, USA.

- 2002. "The Oosterschelde storm surge barrier. A Test Case for Dutch Water Technology, Management, and Politics." Technology and Culture 43 (3): 569-584.

- 2005. "The Vulnerability of Technological Culture”. Pp. 52-69 in Cultures of Technology and the Quest for Innovation. Ed. Helga Nowotny. Berghahn, New York [etc.], USA. 
De Bruin, Dick, Dick Hamhuis, Lodewijk van Nieuwenhuijze, Willem Overmars, Dirk Sijmons, Frans Vera. 1987. Ooievaar. De toekomst van het rivierengebied. [Stork. The future of the rivers region.] Stichting Gelderse Milieufederatie, Arnhem, the Netherlands.

Disco, Cornelis. 2002. "Remaking 'nature': The Ecological Turn in Dutch Water Management.” Science, Technology \& Human Values 27 (2) 206-235

Grabher, G. 1993. "The wekaness of strong ties: the lock-in of regional development in the Ruhr area." Pp. 255-277 in The embedded firm. On the socioeconomics of industrial networks. Ed. G Grabher. Routledge, London,UK.

Heems, Trudes and Baukje Kothuis. 2006. "De tijdgeest als veiligheidsrisico voor waterbeheer: over het belang van sociaal-culturele aspecten bij crisisbeheersing." [On Zeitgeist as a risk factor in water management: the importance of socio-cultural aspects in water management.] Nieuwsbrief crisisbeheersing [Newsletter crisis management] May 2006. Ministry of Home Affairs, The Hague, the Netherlands.

Huisman, Piet (ed.). 1998. Water in the Netherlands. Netherlands Hydrological Society (NHV) special no. 3. Delft, the Netherlands.

Jonkman, Bas, Han Vrijling, Marcel Stive. 2005. "Is de Nederlandse rampenbestrijding voldoende voorbereid op grootschalige overstromingen?" [Is Dutch society suffivciently prepared to deal with large scale flooding?] Nieuwsbrief crisisbeheersing [Newsletter crisis management] April 2005. Ministry of Home Affairs, The Hague, the Netherlands.

Kaijser, Arne. 2002. "System Building from Below: Institutional Change in Dutch Water Control Systems." Technology and Culture 43 (3): 521-548.

Lintsen, Harry. 2002. "Two Centuries of Central Water Management in the Netherlands." Technology and Culture 43 (3): 549-568.

Meijerink, Sander. 2005. "Understanding policy stability and change. The interplay of advocacy coalitions and epistemic communities, windows op opportunity, and Dutch coastal flooding policy 1945-2003." J. European Publ. Pol. 12 (6) 1060-1077.

Ministry of Transport, Public Works and Water Management. 1993. Toetsing uitgangspunten rivierdijkversterkingen. Eindrapport. [Assessment criteria river dike reinforcements. Final report.] The Hague, the Netherlands.

- 2005. Veiligheid Nederland in Kaart. Hoofdrapport onderzoek overstromingsrisico's. [Flood Risks and Safety in the Netherlands. Main report flood risk studies.] The Hague, the Netherlands. Summary in English at http://www.tawinfo.nl/engels/downloads/FloodRisksandSafety.pdf

- 2006a. Leven in een dynamische delta. [Living in a dynamic delta]. The Hague, the Netherlands.

- 2006b. Primaire waterkeringen getoetst. Landelijke rapportage toetsing 2006. [Primary flood defenses tested. Report of national investigations 2006]. Inspection Department of the Ministry of Transport, Public Works and Water Management. Lelystad, the Netherlands. 
Ministry of Transport, Public Works and Water Management \& Ministry for Housing, Spatial Planning and Nature. 1997. "Beleidslijn Ruimte voor de rivier." [Policy guidelines Room for rivers.] Staatscourant 1997, $n r .87$ / pag. 6. The Hague, the Netherlands.

Nieuwsbrief crisisbeheersing [Newsletter crisismanagement]. 2005. "Vier vragen aan Sybe Schaap, voorzitter Unie van Waterschappen." [Four questions to Sybe Schaap, chairman of the Union of Water boards.] September 2005. Ministry of Home Affairs, The Hague, the Netherlands.

- 2006. "Vier vragen aan Mark Dierikx, DG Water." [Four questions to Mark Dierikx, Director-General Water.] May 2006. Ministry of Home Affairs, The Hague, the Netherlands.

Pool, Erik \& Niels Ligthart. 2004. "Kabinetsstrategie Rampenbeheersing overstromingen Rijn en Maas." [Cabinet view on disaster reduction Rhine and Meuse floods.] Nieuwsbrief crisisbeheersing [Newsletter crisis management] July 2006. Ministry of Home Affairs, The Hague, the Netherlands.

Reuss, Martin. 2002. "Learning from the Dutch. Technology, Management and Water Resources Development." Technology and Culture 43 (3): 465-472.

RIVM. 2004. Risico's in bedijkte termen. Een evaluatie van het beleid inzake de veiligheid tegen overstromen. [Dutch dikes, and risk hikes. A thematic policy evaluation of risks of flooding in the Netherlands.] Rijksinstituut voor Volksgezondheid en Milieu (RIVM) [State Institute for Public Health and the Environment], Bilthoven, the Netherlands. Download from http://www.verkeerenwaterstaat.n1/Images/in\%20bedijkte\%20termen\%20-

\%20engelse\%20versie tcm 195-100734.pdf

Roth, Dik, Jeroen Warner, Madelinde Winnubst (2006) Een Noodverband tegen Hoogwater. Waterkennis, beleid en politiek rond noodoverloopgebieden. [An emergency bandage against floods. Knowledge, policy and politics around emergency flood retention areas.] Boundaries of Space series, Wageningen Universiteit and Research Centre, the Netherlands.

Ruimte voor de Rivier website http://www.ruimtevoorderivier.nl/ accessed 8 August 2006

Schwartz, P.G. 1993. "De strategie van Rijkswaterstaat. Leren bij strategische besluitvorming." [Rijkswaterstaat's Strategie. Learning in strategic decision making.] Bestuurskunde 2 (1): 34-41

Silva, Wim. 2002. Hoeveel (hoog)water kan ons land binnen komen via de Rijn bij Lobith, nu en in de toekomst. [How much water could enter our country through the Rhine at Lobith, now and in the future.] RIZA rapport 2003.015, Lelystad, the Netherlands.

Smaal, Aad C., Maarten Knoester, Piet H. Nienhuis\& Patrick M. Meire. 1991. Changes in the Oosterschelde ecosystem induced by the Deltaworks." In: Estuaries and coasts: spatial and temporal intercomparisons. ed. by M. Elliott and J-P. Ducrotoy, Fredensborg : Olsen\& Olsen. Germany.

Steenhuisen, Bauke, Willemijn Dicke, Daniël Tijink. 2006. "Veiligheid verwaterd? Een narratieve analyse van Nederlands en Duits hoogwaterbeleid." ["Safety watered down? A 
narrative analysis of Dutch and German flood management policy."] Bestuurswetenschappen 60 (3) 227-247.

Te Brake, William H. 2002. "Taming the Waterwolf: Hydraulic Engineering and Water Management in the Netherlands during the Middle Ages." Technology and Culture 43 (3): 475-499.

Van de Ven, G.P. (ed.) 1993 Man-made lowlands. History of water management and land reclamation in the Netherlands. International Commission on Irrigation and Drainage \& Royal Institute of Engineers in the Netherlands.

Visie21. 2006. Persbericht Trots en Schaamte van Nederland. [Press release Pride and Shame of the Netherlands]. Project visie21, Utrecht, the Netherlands.

WaterForum Online, 14 September Wesselink, Anna J. 2006. http://waterforum.net/ accessed 14 September 2006

Wesselink, Anna J. 2006a. Safety from flooding in low countries. Position paper. New Directions: Cities and River II Katrina workshop, 21-24 March 2006, New Orleans.

http://www.ndsciencehumanitiespolicy.org/katrina/meetings/marchworkshop.html (accessed 16 July 2006).

- 2006b. Verkenningen hoogwaterbeheer Maas. [Exploration future flood defense Meuse.] Civil Engineering \& Management research report 2006R-003/WEM-004. University of Twente, the Netherlands.

Wiering, Mark and Irene Immink. 2003. "Nieuwe beleidsarrangementen voor water beheer en ruimtelijke ordening?" ["New policy arrangements for water management and spatial planning?"] Pp. 183-196 in Ruimte en Water [Space and Water] eds. Marjan Hidding \& Maarten van der Vlist. No. 5 in Reeks Planologie, Sdu uitgevers, The Hague, the Netherlands.

Wouters, Anita. 2006. Alle zeilen bijzetten. [Raise all sails.] Lecture for the Institute for Governance Studies, University of Twente, 25 April 2006. The Netherlands. 